\title{
MUSIC $\odot_{\mathrm{L}} \odot_{\mathrm{GIST}}$
}

International Joumal of Music Studies

Karadeniz Technical University State Conservatory (C) 2017-2018

Volume 2 Issue $1 \quad$ June 2018

Research Article

Musicologist 2018. 2 (1): 32-48

DOI: $10.33906 /$ musicologist.439311

HİKMET TOKER (1)

Istanbul University, Istanbul, Turkey

hikmet toker@hotmail.com

orcid.org/0000-0003-0337-3825
HALİL İBRAHİM ERBAY (2)

National Palaces, Istanbul, Turkey

erbayhi@gmail.com

orcid.org/0000-0001-7943-1388

\section{The Musical Performance Presented for Sultan Abdülaziz at the Crystal Palace - As an Example Using Music as a Diplomatic Tool ${ }^{1}$}

\begin{abstract}
There are many examples in music history of using music as a political KEYWORDS and diplomatic tool. Governments and monarchs used music for getting positive diplomatic results and similar purposes. This article first aims event organized in Crystal Palace for the imperial guest, Sultan Music and politics Abdülaziz. The article also gives details about Sultan Abdülaziz, his musical vision, and his travel around Europe, as well as the Crystal Palace as the venue of the event.

Several aspects of the event - historical, musical, and political, will be taken into consideration. The conclusion, while analyzing the findings, provides a comparative examination of similar examples about using music as political and diplomatic apparatus in both countries along their own history.
\end{abstract} to give an elaborative account of one such case. The case is a musical Music and diplomacy

Crystal Palace

British music history

\footnotetext{
${ }^{1}$ We are indebted to Sandra E. Franklin for reading the earlier version of this article and her helpful comments.
} 


\section{Introduction}

The visit of Sultan Abdülaziz, the thirty-second Ottoman sultan, to Europe is a unique case in Ottoman history, as it was the first time that an Ottoman monarch visited the European capitals. This work aims to deal with a particular event that took place during the London part of the visit, a musical performance which was carried out in honour of Sultan Aziz in the Crystal Palace in London, although the whole visit has already been studied in several works. Apart from this, we have to mention that Emre Aracı has already dealt with the same subject in one of his works. But, his work is based on limited primary sources about the event. This paper differs from it in a number of ways. First, this work provides more detailed information on Sultan Aziz and the venue of the event, Crystal Palace, depending on primary sources, particularly on archival documents. Another difference from Aracl's work is the approach to the subject. This paper aims to show that music was considered a political and diplomatic tool during the visit of Sultan Aziz, and particularly in the event.

Sultan Abdülaziz, born in 1830 in the Topkapı Palace as the son of Sultan Mahmud II, inherited the throne after his brother Sultan Abdülmecid's death in 1861. In his private life, he lived independently during the reign of Sultan Abdülmecid. For his primary education, he studied the Quran and other religious sciences and then took lessons in calligraphy, music, and drawing. Furthermore, he was very interested in hunting, swimming and wrestling (Küçük, 1998: 472).

An interesting peculiarity of Sultan Aziz was that he was the first member of the Ottoman dynasty who composed in Western musical form. Some sources demonstrate that Sultan Aziz had piano tutorials from an Italian musician, Senior Callisto Guatelli. A British newspaper provides an anecdote on this issue:

Aziz Efendi has always been upon as belonging to old Musluman part; but the following anecdote shows toleration for Christians. Signor Guatelli the late band master had been in the habit of giving lessons on the piano to Abdülaziz Efendi. On the day after the accession of the latter his music master called Palace. He was at once admitted to the presence of the new Sultan who asked him to what he was indebted for 
the honour of the visit. "I have come to give your Majesty your lesson on the piano" was the answer. You know rejoined the Sultan " a Pasha can not condescend to give lesson in music... (Foreign Intelligence (Turkey), 1867)

Some music historians mention that the sultan had four musical pieces in Western musical forms. However, we currently have only one of them, titled Invitation A'la Valse.

One of the sultan's compositions is mentioned in the newspaper article. This means that Sultan Aziz composed a barcarolle, which was played in front of him during his visit. This piece of information is important, as it enables us to detect that the sultan had at least one composition by 1867, the date of his visit.

Soon after he came to the throne in 1861, Abdülaziz faced many difficulties within the empire. Economic problems had increased during the time of his brother's reign, and in many respects, had become nearly insoluble. Nationalist feelings among the minority groups in the empire rose, and some of these groups started to rebel in different parts of the empire.

At the same time, the sovereignty of Ottoman Empire in Egypt was becoming shaky. To sort out this problem, Sultan Aziz made a courtesy visit to Egypt in 1863. Consequently, he received substantial support and favor from the Egyptians during this visit. The sultan attended many meetings, as well as some art events that were organized for him. Abdülaziz brought to Istanbul an Egyptian ensemble that he enjoyed during the visit. This ensemble served at the Ottoman court in Istanbul for a considerable time. On the other hand, Guatelli Paşa, who was the chief and senior educator of the sultan's orchestra, was brought to Egypt by the sultan (Aksüt, 1944: 8).

Sultan Aziz made his second visit during his reign to Europe for the purpose of stabilizing the strained relationship with European countries. First, he accepted the invitation of King Napoleon III of France. Following this visit, the queen of England extended her invitation to him, and he accepted this invitation as well. Furthermore, Sultan Abdülaziz visited Prussia and Austria during this tour. 
The sultan and his entourage set out for their journey to Europe on 21 June 1867. After a long journey, they arrived at the Port of Toulon, then moved to Lyon, and finally, they settled at the Court of Tulieri in Paris. During his stay in Paris, the sultan attended many officially organized events. It can be gathered from the available sources that some of these events were musical performances. For instance, Ali Kemali Aksüt mentions in his book Sultan Aziz'in Misir ve Avrupa Seyahati (The Sultan Abdülaziz's Journey of Egypt and Europe) that the sultan went to a theatre to watch an opera performed to honour him. Aksüt also states that despite the efforts to hide this royal visit to the theatre, the news had quickly circulated in the city, and thousands Parisians gathered in front of the theatre.

Following the sultan's tour in Paris, he and his group continued travel to London. They arrived at the port of Dover on 12 July 1867. The day after, the sultan was accepted by the queen at Windsor Castle, and then he settled in London.

During this visit, he attended many musical performances that were arranged for him. The performances in London are listed below:

- $\quad$ The Royal Ball organized to honor him at Buckingham Palace on 13 July.

- $\quad$ Performance by the Royal Italian Opera in Covent Garden on 15 July.

- $\quad$ Concert and fireworks at the Crystal Palace on 16 July.

- Concert organized by Lord Mayor to the honor of the sultan in the Guildhall on 18 July.

- $\quad$ Ball organized for the sultan in the Indian Office on 19 July.

\section{About the Crystal Palace}

This work, in particular, is about the performance carried out in the Crystal Palace on 16 July 1867. Before going into detail about this concert, it would be useful to provide some information about the Crystal Palace itself.

The first organization of the British Exhibition of National Design was initiated by Prince Albert and Henry Cole on 27 June 1849. (Prince Albert was president of Royal Society and Art, and Henry Cole was an important member of the same society.) 
Somerset House was offered as a place of exhibition, but it was decided to build a specific exhibition hall in Hyde Park because of the lack of room in Somerset. For this purpose, an executive committee was appointed by the Royal Commission, chaired by Robert Stephenson. This commission published their project, but this project was not liked by the public (Musgrave, 1995: 7).

On 16 July 1850, a new and different plan appeared. It was created by Joseph Paxton, the head gardener for the Duke of Devonshire. The main difference between this project and the previous one was the use of iron and glass as the main structure (Musgrave, 1995: 8). After this plan was accepted, the project was completed on 1 May 1851. Despite the fact that it was built in just seven months, the new exhibition hall was commonly called as the Crystal Palace because of its appearance, and it attracted people with its huge size.

The Great Exhibition stayed open for six months. During this time approximately six million people from all over the world visited the exhibition, which hosted thousands of objects, including 1800 musical instruments (Musgrave, 1995: 9).

After the exhibition, it was thought that the Crystal Palace would be destroyed. However, John Paxton prevented such an attempt by founding the Crystal Palace Company. He purchased property for its re-erection in South London and then the foundation for the new Crystal Palace was laid on 5 August 1852. It was completed after a two-year construction period. The newly affixed Crystal Palace became one of the most important leisure places in London (Musgrave, 1995: 9). The Crystal Palace, where many musical events were organized over time, was eventually burnt and destroyed in 1936. 


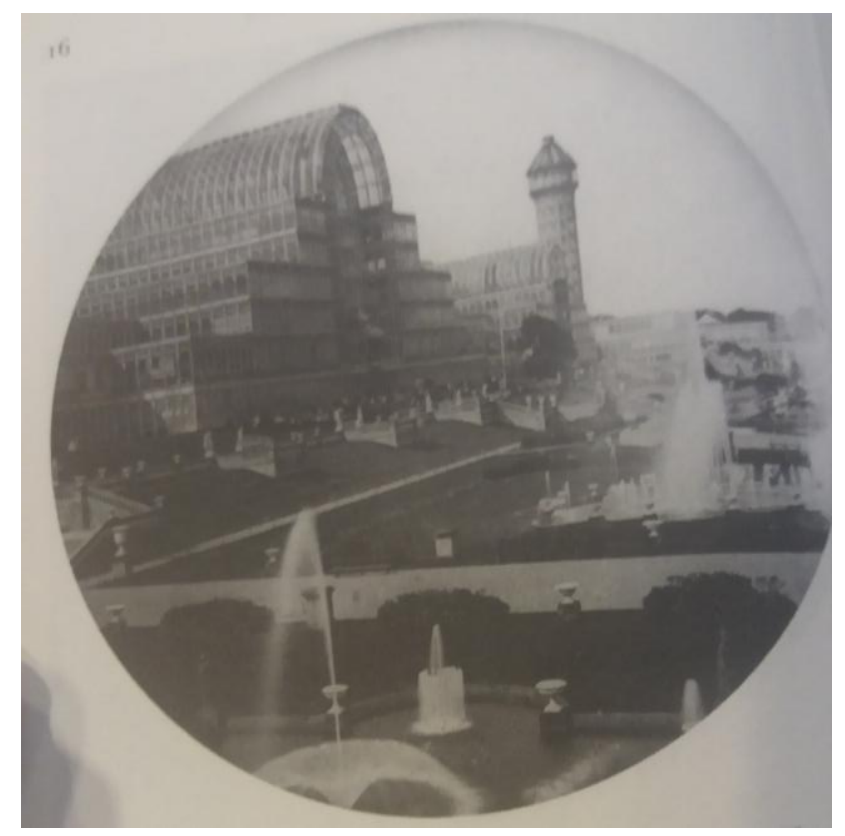

Image 1. A photo of Crystal Palace. (Musgrave, 1995: 16)

\section{About the Musical Performance}

As mentioned, Abdülaziz attended the event at the Crystal Palace in South East London. This event was organized on 16 July 1867, and hundreds of musicians played in this performance.

As can be seen from the sources available in the National Archives, an entertainment committee was created to organize events for the sultan. There are many archival documents, such as dispatches between this committee and the British ambassador in Istanbul at the time. There are also some letters, which were exchanged between the entertainment committee members and Musurus Paşa, the Ottoman ambassador in London at the time (National Archieve, FO 78/2010).

Among these archival documents, only a few are directly about the event in the Crystal Palace. In one of the related documents, the entertainment committee asked for the appropriate date for the sultan for the Crystal Palace event. Another document indicates that the date was settled as 16 July 1867 (National Archive, FO 78/2010).

Additionally, this event was put on the official program of the visit, printed by the British government. The Crystal Palace event was described in the program as follows: 
His Imperial Majesty will be accompanied by his Royal Highness the Prince of Wales and other members of the Royal Family and will afterwards proceed to the Crystal Palace, Where they will arrive little after six o'clock.

After viewing the Grounds the fountains and the principal courts, the imperial party will dine in the Royal Corridor, and, after a concert and a display of fireworks will leave the palace soon after nine o'clock and return to Buckingham palace, escorted as before (National Archive, LC $5 / 28)$.

The sultan attended one musical performance and a bonfire at this event. According to Ali Kemali Aksüt, the choir and the orchestra that night consisted of 2000 musicians.

According to an article in Pall Mall Gazette, a London daily, the program started very late. However, the first part of the program was scheduled for 4:30 afternoon and finished at 8:15 in the evening (Sultan and his Music, 1867: 4). The first part of the program was finished in a timely manner by sacrificing the 'Stirrup Cup' and the 'Spinning Wheel' quartet from Martha.

The concert program included some of the very famous pieces of opera at the time. These pieces were composed by very famous composers, like Bellini, Donizetti, Verdi, Mozart and Mendelssohn. (Aracl, 1998:32)

Another London daily, London Evening Standard, provides some interesting details about the repertoire and performers in its volume published on 17 July 1867 (The Sultan, 1867). According to this article, the concert was divided into two parts. But the British royal family and Sultan Abdülaziz could not attend the first part of the concert. The orchestra and chorus were composed of the Band of Crystal Palace Company and military bands and the Her Majesty Theatre Chorus. All the artists who performed in this event are listed as follows:

Mdlle (mademoiselle) Titiens, Mdlle Christine Nilson Midlle Sipico, Madame Trebelli, Bettini, Madame Demeric-Lablache, Midlle 
Baumeister; Signor Mongini, Signor Gardoni, Signor Tasca, Signor Gassier, Signor Foli, Signor Pandefini, Signor Bossi, Signor Argetti, Her Rokitansky, Her Tom Hohler, Mr. Lyall and Mr. Santley.

Two musicians served as conductors in the concert, Signor Arditi and Mr. Augustus Mans. It is mentioned in the article that Mr. Coward accompanied all these musicians on the great organ.

The program for the first part of the concert and the performers were as follows:

1. Overture, La Gazza Ladra (Rossini).

2. Duetto, Suoni La Tromba, I Prutani (Bellini), Signor Pandolfini and Signor Foli.

3. Rataplan, Al suon del Tamburo (Forza del Destino), (Verdi), Madam Trebelli Bettini, and Chorus of Her Majesty's Theatre.

4. Aria, Loving smile of sister kind, Faust (Gounod), Mr Stanley.

5. $\quad$ Part song, $O$ Hills! O Vales!, Chorus (Mendelssohn).

6. Aria, Ocean thous mighty monster, Oberon, (Weber), Mdlle Titiens.

7. Aria, Una Furtiva lagrima, L’Elisir d'Amore (Donizetti), Signor Gardoni.

8. Aria, Ernani involami, Ernani (Verdi), Mdlle Nilson.

9. Canzone, La donna e mobile, Rigoletto (Verdi), Signor Mongini.

10. Solo and Chorus, Calm as the glassy ocean, Idomeneo (Mozart), Mdlle Sinico and Chorus.

11. Ballad, My Guising Star, Robin Hood (Macfarren), Mr. Hohler.

12. Soldiers, Chorus from Faust (Gounod), the chorus of Her Majesty's Theatre.

13. Polacca, Vien un Giovin, Freischütz (Weber), Mddle Sinico.

14. First Finale of Don Giovanni (Mozart), Mdlle Titiens, Mddle Nilson, Mdlle Sinico, Madame Trebelli Bentini, Mddle Baumeister, Madame DemericLablache, Signor Mongini, Signor Gardoni, Signor Gassier, Signor Pandolfini, Mr. Hohler, Signor Rossi, Signor Folli, Signor Agretti, Mr. Lyall, Herr Rokitansky and Mr. Stanley, with a full band and chorus from her majesty's theatre.

15. Overture, Zampa (Herold).

It can be understood from this article, that the sultan and the Royal Family arrived at the Crystal Palace at the end of the first part of the concert. After they dined in the 
palace building, the second part of the concert started. The repertoire of the second part was as follows:

1. The quartet from the Oberon, Over the dark blue waters sung by Mddle Titiens, Madame Trebelli, Signor Gardoni and Mr Stanley.

2. National Anthem (It could be the Turkish National anthem).

3. New Ode composed by Signor Luigi Arditi.

4. Queen of the Night from the Flauto Magico, sung by Mdlle Nilson.

5. Romanza from the Martha, Signor Mongini.

6. The prayer from Mose (it must be Mose in Egito composed by Rossini) by chorus.

7. The Hallelujah from the Messiah (Handel) by the chorus.(The Sultan, 1867)

The articles on the issue mention that Turkish National Anthem was performed on the arrival of Sultan Abdülaziz at the Crystal Palace. It should be noted here that the article titled Sultan and his Music mentions that Donizetti composed the Turkish National Anthem, which was performed in the Crystal Palace. However, this information was inaccurate because the March of Aziziye, recognized as the Ottoman national anthem during Abdülaziz's reign, was composed by Signor CallistoGuatelli, not by Donizetti. On the other hand, Guiseppe Donizetti composed the March of Mecidiyye which was the national anthem in the time of Abdülaziz's elder brother and predecessor, Sultan Abdülmecid (Sultan and his Music, 1867: 4). Donizetti was also the composer of another march for Sultan Mahmud II, the father of the two successive sultans, Abdülmecid and Abdülaziz.

This article also indicates that large numbers of Londoners were interested in this event. Thousands of people struggled to find a suitable place where they could watch the fireworks easily and acquire the best possible view of the sultan.

Another piece performed that night was an ode composed by Luigi Arditi. Arditi was an Italian conductor and composer, born in 1822. He studied violin and composition at the Milan Conservatory. He composed his first opera, I Briganti, in 1841. After his education, he served as a violin-conductor in Vercelli and Milan. Following this, he worked in different orchestras in Italy and then performed in Canada, USA, and the Ottoman Empire as a conductor. 
After his experience as a conductor in different countries, Luigi Arditi settled in London as the conductor of Her Majesty's Theatre in 1858. He maintained this position for 11 years. In the meantime, he toured with many Italian opera companies.

Between 1878-1894 he was mainly interested in Mapleson's Annual Opera Tour of America. He also worked at different London theatres. Luigi Arditi, who had served in England's musical life many years, died in Essex 1 May 1903 (Burton and Horner, 2001: 866).

The lyrics of this ode were written by Zafiraki Efendi in Turkish. This piece was performed by the choir, numbering 1000 persons, in Turkish. The newspaper also gives some details on this performance:

The ode in honour of his imperial majesty Abul-Aziz, Sultan of Turkey; composed and written by Zafiraki Effendi, and set to music by Signor Arditi, is like Turkish music. You know at once that it is Turkish by the drums in the introduction. Then forgetting all about the drums, you fancy it is only a polka played far too slowly. Then, however, a few Turkish phrases, genuine Turkish phrases, are heard and the imaginative believe themselves in Constantinople. (Sultan and his Music, 1867: 4)

As mentioned in the article, the ode contains some melodic words similar to the Turkish melodic style. Therefore, it is quite possible that this piece was not the first experience for Signor Arditi in Turkish and Turkified music, considering his background in Turkish music while serving in the Ottoman Empire.

When examining the score of this ode, it is noticeable that this piece had been formerly presented to Sultan Abdülmecid, the predecessor and brother of Abdülaziz. EmreAracı states that the score of the ode presented to Sultan Abdülmecid was same as the one presented to Abdülaziz. Aracl also indicates that only the lyrics were different from each other. Consequently, Arditi performed the same composition twice for the two sultans. (Aracl, 1998: 26-27) 
The lyrics of the Ode performed for Sultan Abdülaziz were published in some newspapers at the time as follows:

In the garments of thy gladness, why, O London, art thou bright, As a bride in her apparel, fresh and fair art thou to-night!

Why, P Palace built of diamond, still with fragrant flowers bedight, Do thy stones all flame as rubies, flash and glow with fiery light? The Sultan Abdülaziz comes, hail the cause of our delight!

Mighty ruler over nations, none may with his power compare, Day and night his constant study that his people well may fare; Son of İslam call him Father, Christians own his kindly care. Truly great and wisely powerful, giant action he shall dare, Noble thoughts and aspirations prosper under Osman's heir. (Visit of the Sultan to the Crystal Palace, 1867:4)

After the conclusion of these performances, the sultan gifted 1000 pounds to the performers. An Ottoman archival document refers to this imperial beneficence (BOA, HR.TO, 77/46). According to this document, Sultan Aziz gave 1200 pounds to the management of the Crystal Palace, 200 pounds for the performers and the other 1000 pounds for the reconstruction of some of the places which had been burned in the 1866 fire. During that time, this amount of money was considered to be a fortune. Even the newspapers talked about the size of the donation the sultan had given:

.... to get a true idea of the of the munificence of our Eastern visitors we must remember that the Sultan and the Viceroy of Egypt between them, given to the Crystal Palace exactly three times what the British Parliament, after much deliberation and with much grumbling, has agreed to give annually towards the support of a National Academy. (Sultan and His Music, 1867: 4) 


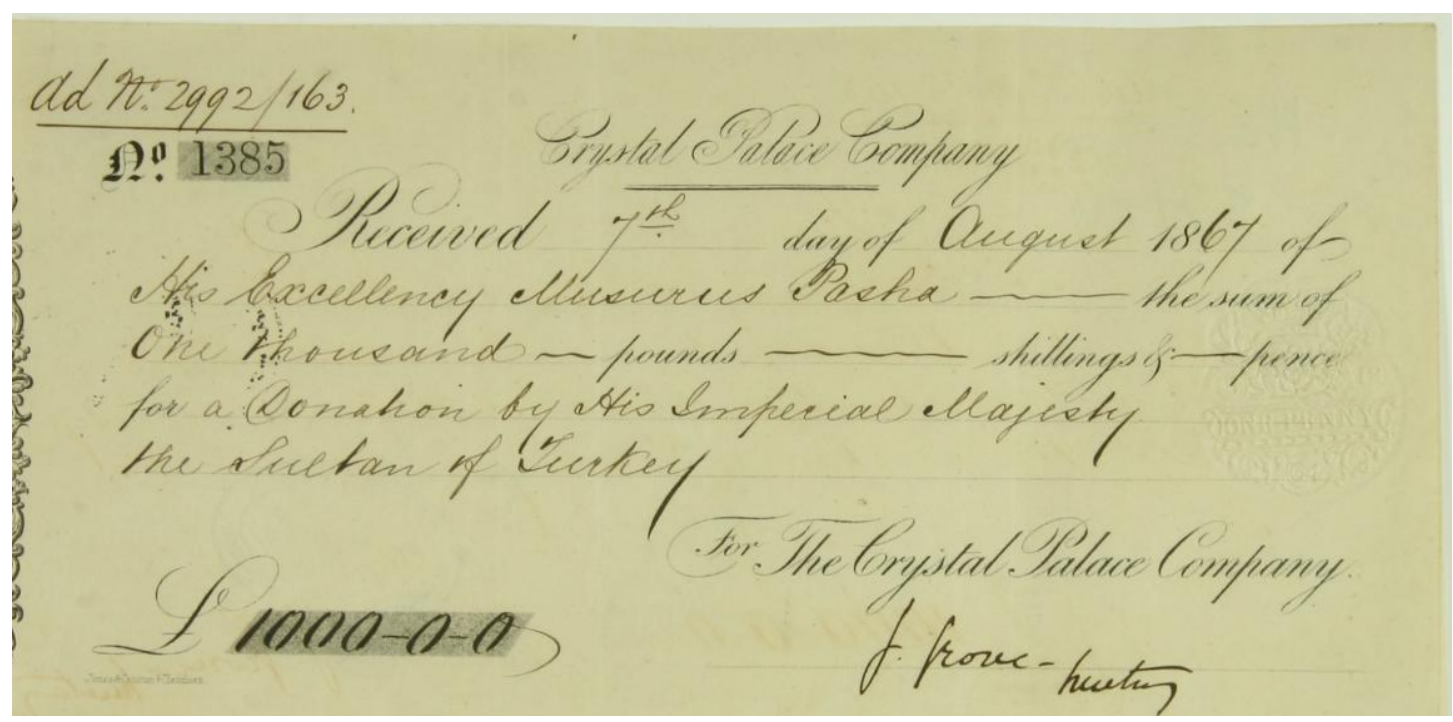

Image 2. Receipt of Abdülaziz's Donation to the Crystal Palace. Ottoman Archives, BOA, HR. T0, 77/46)

As we stated previously, besides these beneficences, Sultan Abdülaziz awarded the medals of Mecidiye to Signor Arditi and to Signor Costa, chief master of the Royal Italian Opera.

\section{Conclusion}

The details provided above provide an example of the use of music as a political instrument. As we can see from some sources, music was used as a political instrument by the British monarchy since the very early times of British history. Musicologist Katherine Butler Schofield mentions how Queen Elizabeth I, who was herself also a Lute player, used music as a political instrument in the following way:

Aware of their political potential, Elizabeth employed the intimacy of private music-making to charm foreign visitors, to develop relations with courtiers and ambassadors, and influence the course of diplomatic negotiations. Moreover, Elizabeth's courtiers began to follow her example, singing or commissioning intimate performances of their own poetry to the Queen in the hope of renewed or continued favour at the expense of their rivals. This politics of intimacy was characteristic of the workings of the Tudor government, in which political power depended on access to the monarch and a courtier's or diplomat's personal relationship with the Queen. In such circumstances recreational 
activities like music gained political significance as a means through which personal relationships could be fostered, which in turn would lead to power and influence (Buttler, 2015: 42).

In addition to this, sources show that Queen Elizabeth I dispatched an organ along with Thomas Dallam, organist and master organ craftsman, to Constantinople in 1599. Thomas Dallam assembled and then played this organ, before the Sultan Mehmed III at the court. (Aracl, 2007: 28)

The main reasons for gifting the organ to the sultan were economic and political. The gift of the organ promoted economic goodwill and facilitated the trading of English business in the Ottoman Empire. In fact, this situation created competition between the British (Levant Company) and the Venetians who dominated trade deals between the Ottoman Empire and Europe (Dallam and Covel, 1892: vii). The second reason for this gift was political. With the gift of the organ, Queen Elizabeth I desired to advance good political relations with Sultan Murat III (father of Sultan Mehmed III) as described by J. Theodore Bent:

Yet another and that a political cause promoted our intercourse with Turkey. Queen Elizabeth was just entering in to her vital contest with Philip II of Spain, and to secure the alliance and co-operation of the Sultan was one of her favourite schemes at this critical juncture.

Even though this information is not directly related with our topic here, it clearly refers to the important phenomenon that music was used as a diplomatic and political tool in the Ottoman past, a very long time before the Crystal Palace concert.

Several examples indicate the use of music to gain positive results in diplomatic relations. Sometimes we can see the effect of using music as a diplomatic tool on some western art pieces. An important case regarding this phenomenon is the illustration created by Hans Holbein (the younger), which shows two ambassadors with some musical instruments and a globe between them. Many researchers state that the instruments and the globe represent harmony in the world. 


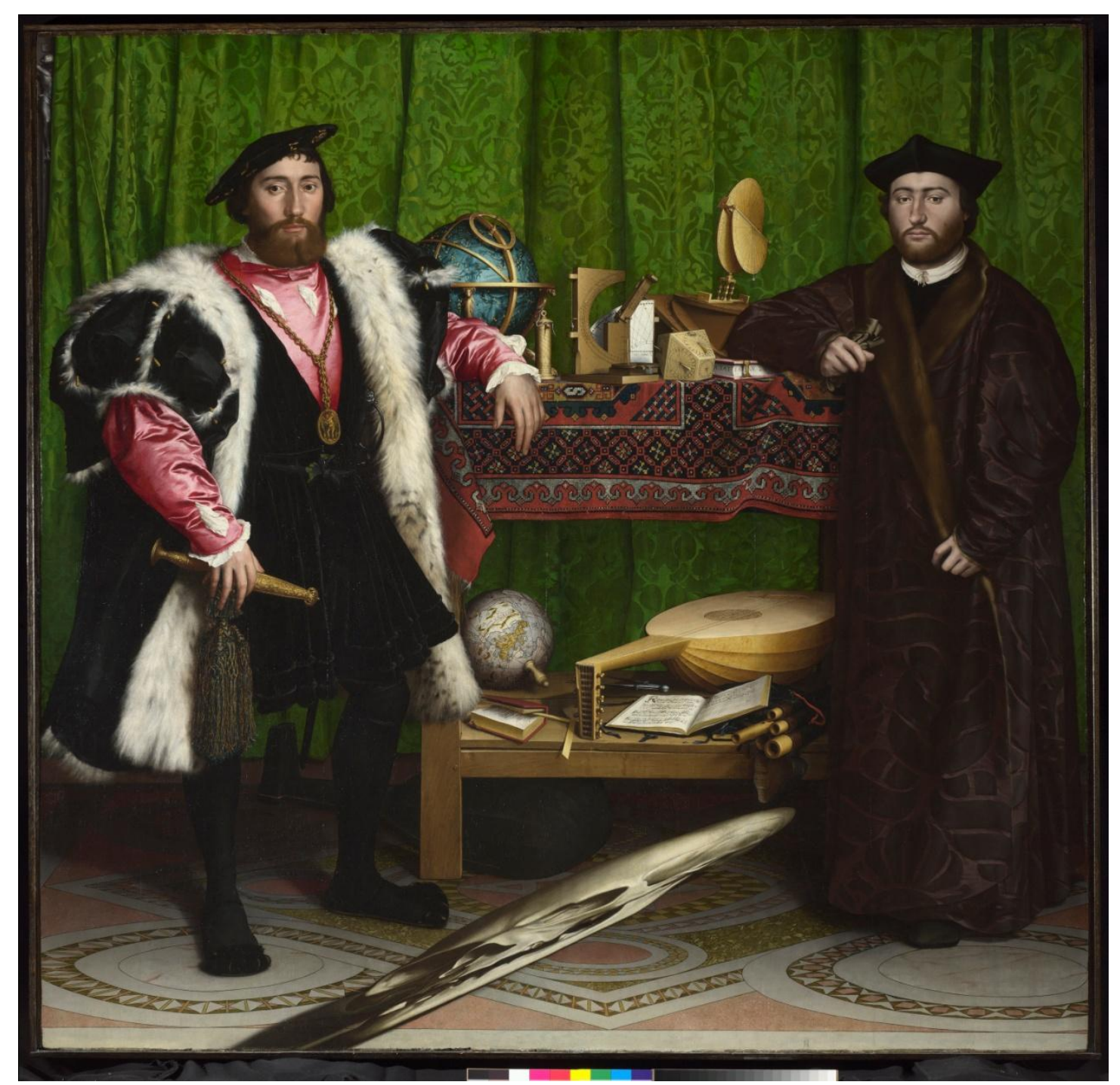

Image 3. The Ambassadors by Hans Holbein (the younger) (Mahiet, 2011: 25)

The sources also show that it was not only Western countries, but also Ottoman rulers, used music in diplomatic relationships.

There are many sources demonstrating the Ottoman use of music in diplomatic ceremonies. For instance, the reception ceremony for the ambassadors in the Ottoman palace started with the marches performed by Musika-i Hümâyûn (the Ottoman Imperial Military Band). (Toker, 2016: 270) There are also many other such occasions in the Ottoman music history as well. The Ottoman protocol registers (teşrifât defterleri) set out the rules of diplomatic receptions and official ceremonies. According to these registers, when an ambassador came to Seraglio to meet the sultan, a military band was to be ready at the palace gate. It can be seen that similar rules applied for the visits of foreign dynasties' members to the Ottoman land. For 
example, a music ensemble was assigned to play music during the Lord and Lady Walse's visit to Turkey (Toker, 2016: 201).

In addition to this, we know that an orchestrate was appointed during the visit of the Shah of Iran to the Ottoman palace (Toker, 2016: 174) and the orchestrate played during dinner time (Örenç, 1998: 71). Such examples demonstrate that the procedure for diplomatic receptions included a musical performance in the Ottoman ceremonial system (Örenç, 1998: 57).

We can see from such cases that all diplomatic events started with music and included some musical aspects in the Ottoman diplomatic system. ${ }^{2}$

In the case of the Crystal Palace event, the huge donation from Sultan Abdülaziz to the performers and to the theatre is another example of the use of music and musical performance as a political instrument. When we think of the generosity of this gift, it seems that, most probably, Sultan Abdülaziz gave that money not only for the purpose of showing his gratitude, but also to show the power of his country and his dynasty.

Awarding the two medals to Luigi Arditi for one composition that was presented to both Sultan Abdülmecid and Sultan Abdülaziz points out that some compositions were seen as just as political object.

You can see this phenomenon in many cases in the Ottoman musical history. When a composer sent his/her composition to the sultan, firstly he had to apply to the Ottoman consulate. After a long diplomatic procedure he/she could get a gift or an award from the sultan in return. There are many examples of composers whose pieces were never played before the sultan because of this long diplomatic process.

Finally, it would not be wrong to argue that music was seen as a good apparatus for influencing the diplomatic relationships in both countries. The Crystal Palace case can be seen as one of the most explicit examples in this regard.

\footnotetext{
2 For further information about the use of music in diplomatic ceremonies in the Ottomans, see, Selçuk Alimdar (2016), Osmanlı'da Batı Müziği, İstanbul: Türkiye İș Bankası Kültür Yayınları, pp. 28-52; Hakan T. Karateke (2004), Padişahım Çok Yaşa!: Osmanlı Devletinin Son Yüzyılında Merasimler, İstanbul: Kitap Yayınevi, pp. 143-54.
} 
This work tried to analyze this case from different perspectives, namely diplomatic, musical and historical. We have seen that this musical performance was designed as a diplomatic tool by the diplomats. In addition, all musical events organized by an entertainment committee for the sultan's visit. The foundation of this committee is quite noteworthy. The archival documents about this committee reveal that all the musical events during the sultan's visit were settled by this committee after a long correspondence between the British and Turkish diplomats. It is also important to see that the educational and artistic background of Sultan Abdülaziz played a role in his approach to music. He was a sultan closely interested in the classical and European styles of music, as can be seen in the case of the Crystal Palace concert and the other performances he attended during his visit.

\section{REFERENCES}

Aksüt, Ali Kemali. (1944). Sultan Abdülaziz'in Mısır ve Avrupa Seyahati [Sultan Abdülaziz's Journey to Egypt and Europe], İstanbul: Ahmet Saidoğlu Publications.

Aracl, Emre. (1998). Londra Crystal Palace'ta Abdülaziz Şerefine Verilen Konser [The Concert Performed in the Crystal Palace in the Honour of Abdülaziz]. Toplumsal Tarih. Vol: 29-33.

Aracı, Emre. (1998). “Luigi Arditi ve Türk Kasidesi'nin Çözülen Esrarı” [Luigi Arditi and the Solved Mystery of the Turkish Kaside]. Toplumsal Tarih. 10(57): 23-27.

Aracı, Emre. (2007). Ahmet Adnan Saygun Doğu-Batı Arasında Müzik Köprüsü [Ahmet Adnan Saygun: A Musical Bridge Between East and West]. İstanbul: Yapı Kredi Yayınları.

Burton, Nigel, and Keith Horner Horner. (2001). "Luigi Arditi". Vol. 1, in The New Grove Dictionary of Music and Musicians, ed. Stanley Sadie: 866-867. London.

Butler, Katherine. (2015). Music in Elizabeth Court Politics. London: The Boydell Press. 
Dallam, Thomas, and John Covel. (1892). Early Voyages and Travels in the Levant. Ed. J. Theodore Bent, F.S.A and F.R.G.S. London: Hakluyt Society.

Küçük, Cevdet. (1998). Abdülaziz (Sultan) [Sultan Abdülaziz]. Türk Diyanet Vakfı Íslam Ansiklopedisi. 1: 472. İstanbul: Türk Diyanet Vakfı Publications.

Mahiet, Damien. (2011). “The Concert of Nations: Music, Political Thought and Diplomacy in Europe, 1600s-1800s". PhD Dissertation, Cornell University, City: Country.

Musgrave, Michael. (1995). The Musical Life of the Crystal Palace. London: Cambridge University Press.

Örenç, İlknur Yıldız. (1998). “Hariciye Teşrifatçılığı Defteri (1846-1880)” [Register of Foreign Office Protocols (1846-1880)]. Master Thesis, Marmara University, Istanbul: Turkey

Toker, Hikmet. (2016). Elhan-ı Aziz [Melodies of [Sultan] Aziz]. İstanbul: Milli Saraylar Daire Başkanlı̆̆l.

Pall Mall Gazette. (1867, July 17). “Sultan and his Music”, p.4.

The Bath Chronicle. (1867, July 11). “Foreign Intelligence (Turkey)”, p.6.

The Era. (1867, July 21). "Visit of the Sultan to the Crystal Palace”, p.10.

London Evening Standard. (1867, July 17). “The Sultan”, p.3.

\section{ARCHIVAL DOCUMENTS}

National Archive, FO 78/2010

National Archive, LC 5/28

Ottoman Archive, BOA, HR. TO, 77/46 